\title{
Carbon film electrodes for oxidase-based enzyme sensors in food analysis
}

\author{
S. De Luca ${ }^{a}$, M. Florescu ${ }^{\text {b }}$, M.E. Ghica ${ }^{\text {b }}$, A. Lupu ${ }^{\text {a }}$, G. Palleschi ${ }^{\text {a }}$, \\ C.M.A. Brett ${ }^{\mathrm{b}, *}$, D. Compagnone $\mathrm{e}^{\mathrm{c}, * *}$ \\ ${ }^{a}$ Dipartimento di Scienze e Tecnologie Chimiche, Università Tor Vergata, via della Ricerca Scientifica, 00133 Rome, Italy \\ ${ }^{\mathrm{b}}$ Departamento de Química, Universidade de Coimbra, 3004-535 Coimbra, Portugal \\ ${ }^{c}$ Dipartimento di Scienze degli Alimenti, Università di Teramo, via C. Lerici 1, 64023 Mosciano S. Angelo, Italy
}

Received 16 May 2005; received in revised form 17 May 2005; accepted 1 June 2005

Available online 20 July 2005

\begin{abstract}
Carbon film resistor electrodes have been evaluated as transducers for the development of multiple oxidase-based enzyme electrode biosensors. The resistor electrodes were first modified with Prussian Blue (PB) and then covered by a layer of covalently immobilized enzyme. Electrochemical impedance spectroscopy was used to characterize the interfacial behaviour of the Prussian Blue modified and enzyme electrodes; the spectra demonstrated that the access of the substrates is essentially unaltered by application of the enzyme layer. These enzyme electrodes were used to detect the substrate of the oxidase (glucose, ethanol, lactate, glutamate) via reduction of hydrogen peroxide at $+50 \mathrm{mV}$ versus $\mathrm{Ag} / \mathrm{AgCl}$ in the low micromolar range. Response times were 1-2 min. Finally, the glucose, ethanol and lactate electrochemical biosensors were used to analyse complex food matrices-must, wine and yoghurt. Data obtained by the single standard addition method were compared with a spectrophotometric reference method and showed good correlation, indicating that the electrodes are suitable for food analysis.
\end{abstract}

(C) 2005 Elsevier B.V. All rights reserved.

Keywords: Oxidase enzymes; Carbon film electrodes; Prussian Blue mediator; Food analysis; Wine

\section{Introduction}

The development of suitable biosensors for food quality monitoring, including the control of raw materials, final products and technological processes, is being actively pursued by scientists both in academia and in industry [1]. In the context of new legislation which creates new market opportunities and stimulates the interest in new test methods, biosensors have to compete with other technologies in terms of price and performance. At present, very few biosensors are used for quality control of technological processes.

\footnotetext{
* Corresponding author. Tel.: +351 239 835295; fax: +351 239835295 .

** Corresponding author. Tel.: +39 0861 266942; fax: +39085 8071509 .

E-mail addresses: brett@ci.uc.pt (C.M.A. Brett),

dcompagnone@unite.it (D. Compagnone).
}

A recent, and growing, trend in the design of electrochemical biosensors involves the production of disposable sensors. In recent years, screen-printed electrodes were used for the development of this kind of biosensors, the screen-printing technique being sufficiently cost-effective to allow the sensors to be treated as disposable [2,3].

Recently, a new electrode material, based on carbon film resistors, has been obtained and characterized electrochemically $[4,5]$. Its very attractive properties, such as a large potential window in the positive and negative directions, robustness of the carbon film, reproducibility of fabrication and ability to further widen the potential range by preconditioning without compromising film integrity, together with cost effectiveness, make this a good material for disposable or easily-renewable sensors. They have been characterized with a view to sensor applications in different electrolyte media of varying $\mathrm{pH}$ by voltammetric techniques and electrochemical 
impedance spectroscopy (EIS) [5]. As substrates for electrochemical biosensors, previous work has entailed use as a glucose sensor by glutaraldehyde cross-linking immobilization of glucose oxidase without mediator [6] and with cobalt hexacyanoferrate redox mediator [7].

This work aims to evaluate the possibility of using these carbon resistors as Prussian Blue modified electrode substrates for the development of biosensors assembled with a variety of oxidase enzymes, for the determination of glucose, ethanol, L-lactate and L-glutamate in food samples.

Prussian Blue (PB) has been shown to be a stable and selective redox mediator at screen-printed electrodes [8-10]. Its stability on carbon resistor substrates is therefore investigated by voltammetric techniques and electrochemical impedance spectroscopy, following formation of PB films by potential cycling, constant current or chemical deposition, in order to investigate which leads to the most robust films. This mediator was already used for the detection of $\mathrm{H}_{2} \mathrm{O}_{2}$ at a potential of around $0.0 \mathrm{~V}$ at screen-printed electrodes, which makes possible the elimination or minimization of possible matrix interferences. The development of amperometric biosensors using PB-modified electrodes was first reported in 1994 [11]. Optimisation of the deposition of PB led to both a stable and selective electrocatalyst for $\mathrm{H}_{2} \mathrm{O}_{2}$ reduction in the presence of oxygen [12]. The current corresponding to $\mathrm{H}_{2} \mathrm{O}_{2}$ reduction on specially-deposited $\mathrm{PB}$ at around $0 \mathrm{~V}$ versus $\mathrm{Ag} / \mathrm{AgCl}$ is about 100 times higher than that of background oxygen and is even higher than at peroxidase-modified electrodes [13]. Due to both its high activity and selectivity in hydrogen peroxide reduction, Prussian Blue has been named as "artificial enzyme peroxidase".

The biosensors developed in this work use oxidase enzymes, which catalyse the general reaction:

Substrate $+\mathrm{O}_{2} \rightarrow$ Product $+\mathrm{H}_{2} \mathrm{O}_{2}$

the hydrogen peroxide then being detected electrochemically, using PB redox mediator. Particular attention has been paid to wine process control: the glucose, ethanol and lactate electrodes have been analysed in must/wine samples. The determination of glucose is very important during the fermentation process and for the final quality control of wine. Ethanol is not only the main product of alcoholic fermentation, but also has an important influence on yeast growth [14]. Concentrations of ethanol above $14 \%$ (v/v) destroy the enzymes involved in fermentation and the process ceases. For the food industry, L-lactate is very useful for evaluating the freshness and stability of milk, diary products, fruits, vegetables, sausages and wines [15]; the lactate electrode has been also tested on yoghurt samples.

Biosensors have previously been reported for the determination of glucose and ethanol in wine [6,10,16-19], of lactic acid in wine $[3,20,21]$ and yoghurt $[2,22]$, and of L-glutamic acid in different food samples [23]. Some of these biosensors used the PB-oxidase system for the detection of hydrogen peroxide.

\section{Experimental}

\subsection{Materials and methods}

Hydrogen peroxide (30\%) was obtained from Merck. All other chemical reagents were analytical grade from Sigma. Those for PB deposition were prepared just before use.

To construct calibration curves, measurements were performed by amperometry at $-0.05 \mathrm{~V}$ versus $\mathrm{Ag} / \mathrm{AgCl}(3 \mathrm{M}$ $\mathrm{KCl}$ ), with a Pt counter electrode, adding known quantities of enzyme substrate. To deposit PB mediator films, a saturated calomel electrode (SCE) was used as reference; the quantity of immobilized mediator was investigated by cyclic voltammetry. The inter- and intra-electrode R.S.D. (\%) were evaluated from the slope of the calibration curves.

Spectrophotometric validation measurements were carried out with commercial Enzytech ${ }^{\mathrm{TM}}$ kits from Scil Diagnostics $\mathrm{GmbH}$.

\subsection{Samples}

Commercial wine (Montepulciano d'Abruzzo, Cabernet, Barbera d'Asti, Bardolino, Colli Albani, Pinot Grigio) and yoghurt (Parmalat-yogurt magro, Danone-bianco cremoso) samples were purchased in a local supermarket in Italy. For the microfermentation, $2 \mathrm{~kg}$ of red grapes were squeezed and $6 \times 10^{7}$ cells mL $\mathrm{mL}^{-1}$ of Saccharomyces cerevisiae were inoculated. The must was kept in a glass container at room temperature for 4 days; exchange of air was ensured by closing the container with cotton wool. Samples $(5 \mathrm{~mL})$ were collected twice a day after mixing of the fermenting juice and centrifuged. The supernatant was diluted in the appropriate buffer for analysis.

\subsection{Apparatus}

Amperometric and voltammetric measurements were performed using an ABD amperometric detector, Universal Sensors and an Autolab PGSTAT Bipotentiostat with GPES 3 software (EcoChemie, Netherlands).

Electrochemical impedance measurements were performed using a Solartron 1250 frequency response analyser coupled to a Solartron 1286 electrochemical interface (Solartron Analytical, UK) controlled by ZPlot software. Spectra were recorded in the frequency range $65 \mathrm{kHz}-0.1 \mathrm{~Hz}$ with a signal amplitude of $10 \mathrm{mV}$ and 10 data points per frequency decade.

For the spectrophotometric measurements a UNICAM $8625 \mathrm{UV}$-vis spectrophotometer was used.

\subsection{Carbon film electrode preparation}

Carbon film electrodes were made from carbon film electrical resistors ( $2 \Omega, 15 \mu \mathrm{m}$ carbon film thickness), which are fabricated from ceramic cylinders of length $0.6 \mathrm{~cm}$ and external diameter $0.15 \mathrm{~cm}$ by pyrolytic deposition of carbon, as 
described elsewhere [4]. Briefly one of the two metal caps with contact wire was removed from one end, and the other was used as the external electric contact, the wire being protected by a plastic tube and the contact cap area being insulated using epoxy resin. The exposed electrode area was $\sim 0.20 \mathrm{~cm}^{2}$.

\subsection{Prussian Blue deposition}

For the deposition of Prussian Blue mediator film, three techniques were investigated: galvanostatic, constant potential and cyclic voltammetry deposition.

Galvanostatic deposition was carried out from a solution containing $20 \mathrm{mM} \mathrm{K}_{3}(\mathrm{FeCN})_{6}, 20 \mathrm{mM} \mathrm{FeCl}_{3}, 0.1 \mathrm{M} \mathrm{KCl}$ and $0.1 \mathrm{M} \mathrm{HCl}$ by applying a constant current of $-3 \mu \mathrm{A}$ for $2 \mathrm{~min}$.

Constant potential deposition was carried out at $+0.4 \mathrm{~V}$ versus $\mathrm{SCE}$, for $1 \mathrm{~min}$, in a solution of $2 \mathrm{mM} \mathrm{K}_{3}(\mathrm{FeCN})_{6}$, $2 \mathrm{mM} \mathrm{FeCl}_{3}, 0.1 \mathrm{M} \mathrm{KCl}$ and $0.1 \mathrm{M} \mathrm{HCl}$.

Cyclic voltammetric deposition was carried out in a solution of $1 \mathrm{mM} \mathrm{K}_{3}(\mathrm{FeCN})_{6}, 1 \mathrm{mM} \mathrm{FeCl}_{3}, 0.1 \mathrm{M} \mathrm{KCl}$ and $0.1 \mathrm{M}$ $\mathrm{HCl}$, by scanning for 25 cycles between -0.1 and $0.5 \mathrm{~V}$ versus SCE, at a scan rate of $10 \mathrm{mV} \mathrm{s}^{-1}$.

The films obtained were stabilized by keeping the electrodes in an oven at $100{ }^{\circ} \mathrm{C}$ for $90 \mathrm{~min}$.

The presence of the PB film was confirmed by performing cyclic voltammetry in $0.05 \mathrm{M}$ phosphate buffer, $\mathrm{pH} 7.4$. The PB-modified electrodes were stored at room temperature in the dark.

\subsection{Enzyme immobilization}

Three immobilization techniques were investigated for glucose oxidase (GOx). For the "drop-coating" technique, $1 \mathrm{mg}$ of glucose oxidase (from Aspergillus Niger, $181 \mathrm{U} \mathrm{mg}^{-1}$ ) and $4 \mathrm{mg} \mathrm{BSA}$ were dissolved in $100 \mu \mathrm{L}$ of $0.1 \mathrm{M}$ phosphate buffer $\mathrm{pH} 7.4$. A volume of $10 \mu \mathrm{L}$ of this solution was then mixed with $5 \mu \mathrm{L}$ glutaraldehyde solution $(2.5 \%)$ and $10 \mu \mathrm{L}$ of this mixture was then equally spread over the electrode surface. The electrode was left to dry for $20 \mathrm{~min}$ and then immersed in a $0.1 \mathrm{M}$ solution of glycine. The sensor was stored in buffer, in the dark.

For the "dip and dry" method, the electrode was immersed for 5 or $15 \mathrm{~min}$ in the enzymatic mixture, then left to dry and saturated in glycine as described above.

The PEI-based technique consisted in the immobilization of the enzyme in a polymeric film of polyethyleneimine (PEI) in three steps. First, the electrode was immersed in a $2 \%$ solution of PEI, for $30 \mathrm{~min}$, then in $2.5 \%$ glutaraldehyde for another $30 \mathrm{~min}$ and finally for $30 \mathrm{~min}$ in $0.01 \mathrm{mg} \mathrm{mL}^{-1}$ GOx solution. The electrode was stored at $4{ }^{\circ} \mathrm{C}$, in buffer.

All the other oxidases were immobilized only by the "drop-coating" technique, using enzymatic solutions of alcohol oxidase from Pichia Pastoris, $45 \mathrm{mg} \mathrm{mL}^{-1}$, L-lactate oxidase from Pediococcus sp., $9.3 \mathrm{U} \mathrm{mL}^{-1}$ and L-glutamate oxidase from Streptomyces sp., $1 \mathrm{U} \mathrm{mL}^{-1}$.

\section{Results and discussion}

\subsection{Prussian Blue deposition}

The method chosen for deposition of the PB film on the electrode surface is very important for obtaining a mediator film with a regular structure, and hence a stable catalytic film. For this reason, three deposition techniques were investigated, taking into consideration the particular behaviour of this mediator and the fact that the deposition is highly dependent on the electrode support [24]. The deposition of Prussian Blue onto various conductive surfaces is usually carried out from aqueous solutions containing a mixture of ferric $\left(\mathrm{Fe}^{3+}\right.$ and ferricyanide $\left(\left[\mathrm{Fe}^{\mathrm{III}}(\mathrm{CN})_{6}\right]^{3-}\right)$ ions, either spontaneously in an open-circuit regime or by applying a reductive driving force [14]. Fixed potential, galvanostatic and cyclic voltammetric deposition techniques were studied.

Fig. 1a shows the variation of current during fixed potential deposition, Fig. $1 \mathrm{~b}$ the variation of electrode potential due to the applied cathodic current, during galvanostatic deposition and Fig. 1c the increment in peak current, due to an increased quantity of mediator, during cyclic voltammetric deposition. It was found that films deposited by the galvanostatic technique had less mediator, a higher capacitive current and showed poor reversibility. The largest quantity of mediator was deposited by cyclic voltammetry, and its good voltammetric profile reveals a better quality of the crystal structure due to the slower growth. The determining factor is probably the cleaning and activation of the electrode surface, obtained by successive scans in acidic medium. Studies carried out with pretreated (cycling in perchloric acid [4]) and un-pretreated electrodes showed very small differences. The surface coverage, in the case of the electrodes modified by voltammetric deposition, was calculated as $\Gamma=2.6 \times 10^{-8} \mathrm{~mol} \mathrm{~cm}^{-2}$. It was also found that crystal growth is promoted by slower scan rates $\left(10 \mathrm{mV} \mathrm{s}^{-1}\right)$, confirming the fact that a slower process leads to a more regular crystal structure.

The calibration curve for measurement of hydrogen peroxide, obtained at $-0.050 \mathrm{~V}$ versus $\mathrm{Ag} / \mathrm{AgCl}$ in stirred solution (0.1 M phosphate buffer $\mathrm{pH} 7.0)$, led to a detection limit of $0.5 \mu \mathrm{M}$ (calculated as three times the standard deviation of the noise signal), a linear range up to $10 \mathrm{mM}$ and a sensitivity of $51 \mu \mathrm{A} \mu \mathrm{M}^{-1}$.

\subsection{Enzyme immobilization}

The three different techniques described in the experimental section, i.e. drop-coating, dip and dry, and the PEI-based technique for immobilization of glucose oxidase on the electrode surface were compared, in order to optimise the sensor response. The analytical results using these three techniques are reported in Table 1.

It can be noticed that all the procedures resulted in the construction of useful enzyme electrodes. The PEI-based technique gave the poorest detection limit and sensitivity; this 

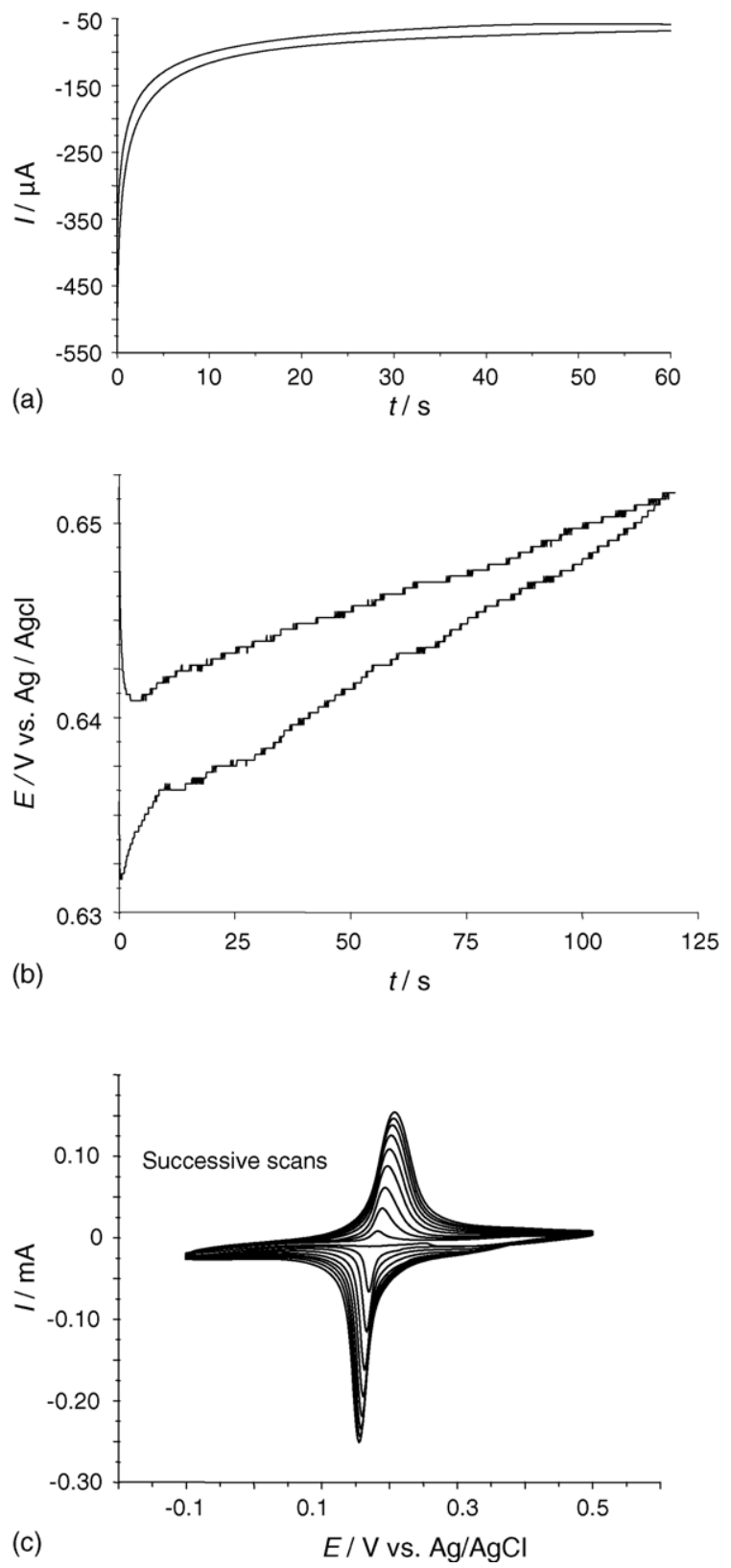

Fig. 1. Typical deposition profiles of Prussian Blue by (a) constant applied potential of $0.4 \mathrm{~V}$ vs. SCE for $1 \mathrm{~min}$; (b) galvanostatic deposition, applied current $-3 \mu \mathrm{A}$ for $2 \mathrm{~min}$; (c) cyclic voltammetry, 25 successive scans at $10 \mathrm{mV} \mathrm{s}^{-1}$. can be attributed to the low enzyme loading/membrane thickness ratio. The other two immobilization procedures gave comparable performances in terms of sensitivity, detection limit, linearity range, and intra-electrode R.S.D. (calculated on the sensitivity obtained for five consecutive calibration curves). The drop-coating technique was finally selected for the immobilization of the other oxidase enzymes because of the lower inter-electrode R.S.D. (calculated on the sensitivity of three calibration curves for each of six enzyme electrodes prepared in 2 days).

\subsection{Characterization by electrochemical impedance spectroscopy}

Electrochemical impedance spectroscopy can be used to determine quantitative parameters of electrode processes as well as to provide a fingerprint of the interfacial region. EIS has been used to investigate the carbon film electrodes used in this work in a variety of electrolytes at different $\mathrm{pH}$ values, with and without pretreatment by cycling in acid solution [5], as well as at non-mediated glucose biosensors with carbon film substrate [6]. Similar measurements have been done at the biosensor assemblies used here in order to understand how the surface modification influences the electrode processes. In Fig. 2 are shown complex plane impedance plots measured at $0.0 \mathrm{~V}$ versus $\mathrm{SCE}$ in $0.05 \mathrm{M}$ phosphate buffer $+0.1 \mathrm{M}, \mathrm{pH}$ 7.40 for bare, PB-modified and PB-enzyme modified carbon film resistor electrodes. These spectra were reproducible and Fig. 2 shows the maximum variation in response obtained between different electrodes.

Regarding the bare carbon film electrodes, Fig. 2a, the spectra are indicative of a single time-constant electrode process and can be modelled by an electrical equivalent circuit consisting of the cell resistance, $R_{\Omega}$, in series with a parallel $R_{1} \mathrm{CPE}_{1}$ combination with $R_{1}$ representing the charge transfer resistance. The CPE is assumed to be a non-ideal capacitance, value $C_{1}$, with phase angle exponent $\alpha_{1}$. Using this approach, values of $R_{1}$ of approximately $200 \mathrm{k} \Omega$ are obtained, of $C_{1} 5.5 \mu \mathrm{F}$ (corresponding to values of $40 \mathrm{k} \Omega \mathrm{cm}^{2}$ and $27.5 \mu \mathrm{Fcm}^{-2}$, respectively) and the phase angle exponent is 0.85 , as is usually found at different types of carbon electrode [5].

These electrodes were then coated with PB. At PBmodified electrodes, Fig. 2b, the spectra can be modelled by the same equivalent circuit with the addition of a second constant phase element, $\mathrm{CPE}_{2}$ representing a second

Table 1

Characteristics of "drop-coating", "dip and dry" and PEI-based immobilization techniques

\begin{tabular}{lllcll}
\hline $\begin{array}{l}\text { Immobilization } \\
\text { technique }\end{array}$ & $\begin{array}{l}\text { Sensitivity } \\
\left(\mu \mathrm{Am}^{-1}\right)\end{array}$ & $\begin{array}{l}\text { Detection } \\
\text { limit }(\mu \mathrm{M})\end{array}$ & $\begin{array}{l}\text { Linearity } \\
\text { range }(\mu \mathrm{M})\end{array}$ & $\begin{array}{l}\text { R.S.D. } \\
\text { intra-electrode }(\%)\end{array}$ & $\begin{array}{l}\text { R.S.D. } \\
\text { inter-electrode }^{\mathrm{b}}(\%)\end{array}$ \\
\hline Drop-coating & 8.0 & 1 & $5-800$ & 4 & 10 \\
Dip and dry & 6.5 & 1 & $5-700$ & 6 & 40 \\
Multistep & 0.4 & 10 & $20-800$ & 5 & 25 \\
\hline
\end{tabular}

\footnotetext{
${ }^{a}$ Calculated from the sensitivity obtained for five consecutive calibration curves.

${ }^{\mathrm{b}}$ Calculated from the sensitivity obtained for three consecutive calibration curves of six enzyme sensors prepared during 2 days.
} 

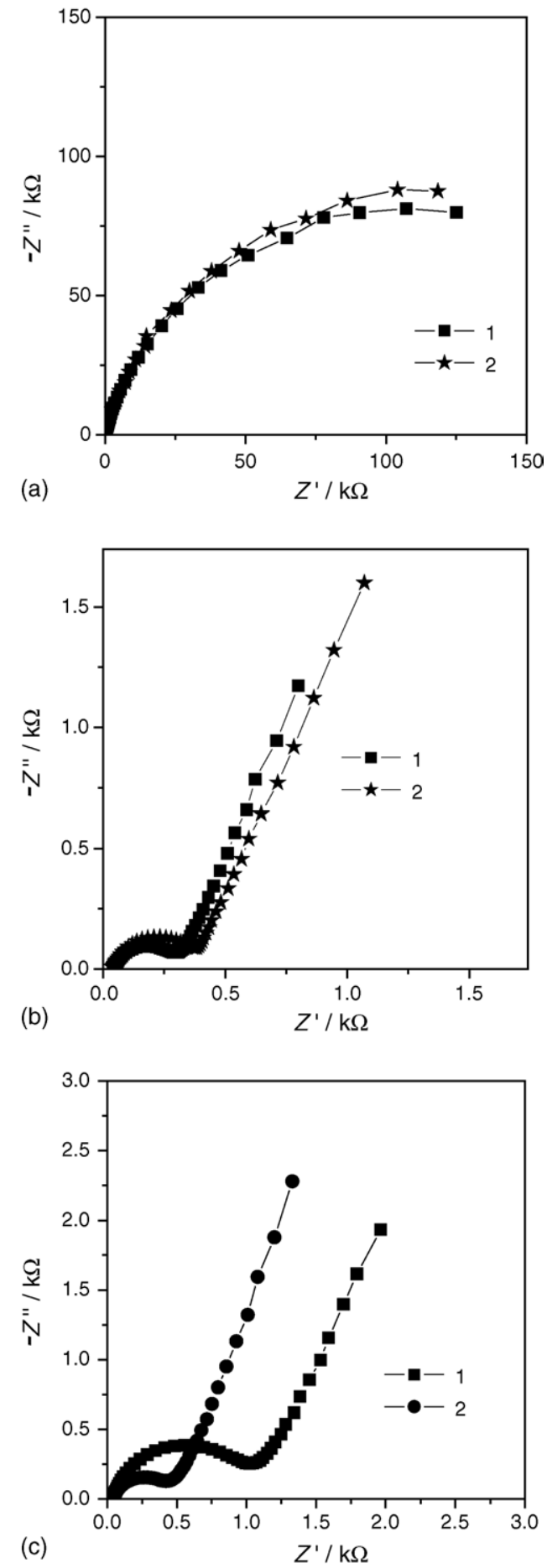

Fig. 2. Complex plane impedance spectra for (a) unmodified; (b) PBmodified; (c) PB/enzyme-modified carbon film electrodes at two different electrodes. Spectra were recorded at $0.0 \mathrm{~V}$ vs. SCE in $0.05 \mathrm{M}$ phosphate buffer $+0.1 \mathrm{M} \mathrm{KCl}, \mathrm{pH} 7.4$.

non-ideal capacitance in series with the $R_{1} \mathrm{CPE}_{1}$ parallel combination. In this case, $R_{1} \mathrm{CPE}_{1}$ represents processes at the $\mathrm{PB} /$ electrolyte interface and $\mathrm{CPE}_{2}$ charge separation within the conducting film. Values obtained for electrode 1 are $R_{1}=54 \Omega \mathrm{cm}^{2}, C_{1}=120 \mu \mathrm{F} \mathrm{cm}^{-2}, \alpha_{1}=0.75$ and
$C_{2}=5.6 \mathrm{mF} \mathrm{cm}^{-2}$ and $\alpha_{2}=0.75$. From these values several conclusions can be taken. First, there is evidence of a series charge separation occurring, presumably at the PB film/electrolyte interface owing to the discontinuities in the crystal structure. Secondly, the phase angle exponent is lower, indicating increased surface roughness compared to the bare carbon film. The second electrode, electrode 2 in Fig. 2b, presents slightly different values of the various parameters. Comparison of Fig. 2b with Fig. 2a shows that the impedance of the PB-coated carbon film, which reflects processes at the $\mathrm{PB} / \mathrm{electrolyte}$ interface, has significantly changed with respect to the bare carbon/electrolyte interface.

The spectra of two different PB-GOx-modified carbon resistor electrodes are shown in Fig. 2c. The shape is almost unaltered with respect to the PB-modified electrodes, both in the absence and in the presence of glucose enzyme substrate (not shown). This indicates that the access of electroactive species to the PB surface and the redox processes occurring is essentially unaltered by the application of the enzyme layer and the enzyme-substrate reaction. Continuous recording of spectra shows no difference in five consecutive measurements for each electrode.

It can be seen that electrochemical impedance is an excellent complementary tool and a good diagnostic for the presence of the mediator film and of the characteristics of the surface processes and any changes that may occur. In particular, it has shown that the enzyme layer does not alter the functioning of the mediator layer underneath it.

\subsection{Biosensors for glucose, ethanol, L-lactate and L-glutamate}

The analytical behaviour of the assembled biosensors (obtained in $0.1 \mathrm{M}$ phosphate buffer $\mathrm{pH}$ 7.0) is reported in Table 2. Similar detection limits and linearity ranges were obtained for all the enzyme electrodes. Small differences in sensitivity and apparent $K_{\mathrm{m}}$ values (calculated from Lineweaver-Burk plots), can be attributed to the different specific activity of the purified enzymes. The intra-electrode R.S.D., calculated from linear regressions of five consecutive calibration curves, were quite good, while inter-electrode repeatability (calculated as in Table 1) is around $10 \%$ for glucose to $30 \%$ for ethanol.

The biosensors obtained demonstrate detection limits comparable with those previously reported for platinumbased biosensors, even though the linear range is smaller, probably due to a different immobilization of the enzyme $[25,26]$. In general, analytical performances are comparable with the best obtained using carbon based Prussian Blue modified electrodes coupled with oxidase enzymes, including screen-printed based enzyme electrodes [16,27-29].

The lifetime of the enzyme electrodes was evaluated by running two calibration curves per week on electrodes stored in $0.1 \mathrm{M}$ phosphate buffer $\mathrm{pH} 7.0$ at $4{ }^{\circ} \mathrm{C}$. After 1-month storage the glucose and glutamate enzyme sensors still retained 
Table 2

Characteristics of carbon film resistor enzyme electrodes

\begin{tabular}{|c|c|c|c|c|c|c|}
\hline Analyte & Enzyme & $K_{\mathrm{m}, \mathrm{app}}{ }^{\mathrm{a}}(\mu \mathrm{M})$ & Sensitivity $\left(\mu \mathrm{A} \mathrm{mM}^{-1}\right)$ & Detection limit $(\mu \mathrm{M})$ & Linear range $(\mu \mathrm{M})$ & R.S.D. ${ }^{b}(\%)$ \\
\hline Glucose & Glucose oxidase & 530 & 8 & 1 & $10-800$ & 4 \\
\hline Ethanol & Alcohol oxidase & 420 & 5.5 & 1 & $10-700$ & 6 \\
\hline L-Lactate & L-Lactate oxidase & 310 & 10.4 & 1 & $10-500$ & 8 \\
\hline L-Glutamate & L-Glutamate oxidase & 380 & 7 & 1 & $10-700$ & 6 \\
\hline
\end{tabular}

a Apparent $K_{\mathrm{m}}$ calculated using a Lineaweaver-Burk plot.

b Calculated from the sensitivity obtained for five consecutive calibration curves.

$50-60 \%$ of the initial activity, while the activity for ethanol and lactate sensors was in the $20-40 \%$ range.

\subsection{Analysis of food samples}

\subsubsection{Glucose and ethanol determination}

After optimisation of all experimental parameters, the biosensors for glucose and ethanol were used to monitor an alcoholic fermentation carried out in the laboratory as reported in the experimental section. The results, obtained by the single standard addition method on samples diluted appropriately in buffer (from 1:200 to 1:2000), are presented in Fig. 3. Measurements were done in triplicate with the enzyme electrodes and with spectrophotometric enzymatic kits. The data clearly show that both sensors are suitable for the measurement of glucose/ethanol in a sample such as must and for the monitoring of alcoholic fermentation processes.

Considering wine as sample, greater problems in the determination of glucose than of ethanol can be expected because of its low concentration at the end of the fermentation (dry wines). In order to evaluate the effect that this complex matrix can have on the measurements, recovery studies were carried out by running complete calibration curves for glucose in different dilutions of two bottled dry red wines, Montepulciano d'Abruzzo and Pinot Nero, both of which have a high concentration of phenolic compounds that can interfere with

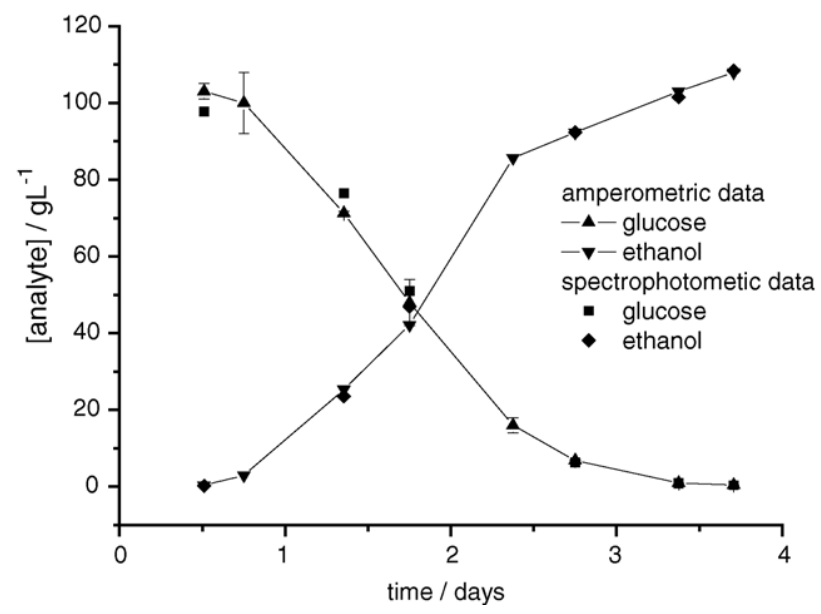

Fig. 3. The fermentation profile (glucose and ethanol) obtained with carbon film resistor based biosensors and spectrophotometric commercial enzymatic kits. electrochemical measurements. It was observed that even at dilutions of 1:25 (data not shown) the sensitivity was constant for successive experiments, with a typical recovery around $100 \%$ for glucose. This behaviour demonstrates that the sensor is appropriate even for accurate determination of residual glucose in dry wines, with expected concentration values lower than $1 \mathrm{~g} \mathrm{~L}^{-1}$. In fact, a detection limit of $0.1 \mathrm{~g} \mathrm{~L}^{-1}$ of glucose (calculated as three times the S.D. of the noise of the blank in the presence of wine sample diluted 1:25) in red wines was obtained. The recovery value was higher than previously reported for a recently developed Prussian Blue glucose sensor based on screen-printed electrodes [16] for which a matrix effect was observed at 1:100 dilution of wine (glucose oxidase immobilized via PEI). Differences between these two enzyme sensors can be attributed to the different diffusion profile of samples and oxygen availability through the enzymatic layer. The data obtained confirm the excellent selectivity of carbon based Prussian Blue modified electrodes as catalysts for the reduction of $\mathrm{H}_{2} \mathrm{O}_{2}$ in complex matrices. Other disposable or low cost carbon based enzyme electrodes reported in the literature for detection of glucose in complex matrices exhibited either poorer sensitivity and/or necessity of interference removal [30-32].

The glucose and ethanol sensors were then tested for determination of glucose and ethanol in four red and two white wines and the results were compared with spectrophotometric data, using a commercial enzymatic kit. Table 3 reports the results obtained using the single standard addition method for the sensors. It can be observed that for the determination of ethanol the amperometric and spectrophotometric values are in good agreement with relative errors below $10 \%$. In order to further demonstrate the interchangeability of the measurement performed with the developed biosensors and the enzymatic kits, we applied the treatment of Altman and Bland [33] to the data. The mean difference (d) obtained was 0.008 and -1.33 for glucose and ethanol, respectively. We can, then, affirm that $95 \%$ of the data will lie in the $d \pm 2 s$ interval where $s$ is representing the standard deviation of the differences. Thus, for analysis of glucose in dry wines (concentration below $1 \mathrm{~g}^{-1} \mathrm{~L}^{-1}$ ) the biosensor can overestimate the spectrophotometric kit analysis up to $0.063 \mathrm{~g} \mathrm{~L}^{-1}$ or underestimate down to $0.049(s=0.0285)$; for ethanol (concentration around $100 \mathrm{~g} \mathrm{~L}^{-1}$ ), overestimation resulted to be $+8.7 \mathrm{~g} \mathrm{~L}^{-1}$ and underestimation $-11.3 \mathrm{~g} \mathrm{~L}^{-1}$ $(s=5.005)$. We can conclude that the two methods can be used interchangeably for glucose and ethanol determination 
Table 3

Amperometric and spectrophotometric data for the determination of glucose, ethanol and lactate in different wines and yoghurts

\begin{tabular}{|c|c|c|c|c|c|c|c|c|c|}
\hline & \multicolumn{3}{|l|}{ Glucose $\left(\mathrm{g} \mathrm{L}^{-1}\right)$} & \multicolumn{3}{|l|}{ Ethanol $\left(\mathrm{g} \mathrm{L}^{-1}\right)$} & \multicolumn{3}{|l|}{ Lactate $\left(\mathrm{g} \mathrm{L}^{-1}\right)$} \\
\hline & Amperometric & Spectrophotometric & $\Delta(\%)$ & Amperometric & Spectrophotometric & $\Delta(\%)$ & Amperometric & Spectrophotometric & $\Delta(\%)$ \\
\hline \multicolumn{10}{|l|}{ Wine } \\
\hline $\begin{array}{c}\text { Montepulciano } \\
\text { d'Abruzzo }\end{array}$ & $0.57 \pm 0.01$ & 0.62 & +8 & $94 \pm 10$ & 99 & +5 & $1.9 \pm 0.3$ & 1.8 & -5 \\
\hline Cabernet & $0.14 \pm 0.01$ & 0.15 & +7 & $97 \pm 4$ & 97 & 0 & $2.0 \pm 0.4$ & 2.2 & +9 \\
\hline Barbera d'Asti & $0.42 \pm 0.02$ & 0.39 & -7 & $110 \pm 20$ & 101 & -8 & $1.6 \pm 0.1$ & 1.7 & +6 \\
\hline Bardolino & $0.47 \pm 0.02$ & 0.43 & -9 & $100 \pm 10$ & 99 & -1 & $1.8 \pm 0.1$ & 2.0 & +10 \\
\hline Colli Albani & $0.19 \pm 0.01$ & 0.20 & +5 & $94 \pm 2$ & 96 & +2 & $1.8 \pm 0.3$ & 1.9 & +5 \\
\hline Pinot Grigio & $0.32 \pm 0.01$ & 0.29 & -9 & $103 \pm 9$ & 98 & -5 & $1.8 \pm 0.1$ & 1.7 & -6 \\
\hline \multicolumn{10}{|l|}{ Yoghurt } \\
\hline $\begin{array}{l}\text { Parmalat-yogurt } \\
\text { magro }\end{array}$ & & & & & & & $7.2 \pm 0.4$ & 8.2 & +13 \\
\hline $\begin{array}{l}\text { Danone-cremoso } \\
\text { bianco }\end{array}$ & & & & & & & $6.8 \pm 0.3$ & 8.0 & +15 \\
\hline
\end{tabular}

since the calculated differences are not significantly different. Similar data were obtained for analysis of lactate in wines (see next paragraph).

\subsubsection{L-Lactic acid determination in wine and yoghurt samples}

The lactate sensor was tested in wine and yoghurt samples. The recovery studies exhibited, in this case, a matrix effect at 1:50 dilution of wine ( $90 \%$ recovery). However, considering that the concentration of lactic acid in wine ranges from 1 to $4 \mathrm{~g} \mathrm{~L}^{-1}$, this does not influence the accuracy of the determination. The data obtained correlated well with enzymatic spectrophotometric determination as reported in Table 3 with relative errors comparable to those obtained for glucose and ethanol determination. The Bland and Altmann analysis of the data gave $95 \%$ of the differences between the two methods lying in the $0.067 \pm 0.27 \mathrm{~g} \mathrm{~L}^{-1}$ range.

Yoghurt samples required a higher dilution. Nevertheless, a matrix effect was observed also for dilutions of 1:500. Interference from cations as $\mathrm{Ca}^{2+}$ (high amount in yoghurt samples) was already reported for lactate oxidase-based biosensors [2,31]; moreover $\mathrm{Ca}^{2+}$ ions have been reported to affect the mediator [22]. However, the recovery obtained at that dilution (85-90\%) allowed the detection of lactate in the two samples with a relative error of $13-15 \%$.

\section{Conclusions}

The oxidase-PB-modified carbon film resistor electrode biosensors are comparable with screen-printed biosensors in terms of sensitivity and detection limit and without a consistent matrix effect. The detection limits are also similar to those previously reported for platinum-based biosensors. Moreover, they are cheap and have the possibility of being used for different analytes, which makes them suitable for on-line monitoring and for screening of food products.

The different design, relative to screen-printed electrodes, allows the use of different procedures for the immobilization of biological compounds. Moreover, the surface is cleaner and, thus, more suitable for electrochemical applications, due to the absence of additives normally present in inks used for screen-printing.

It has been demonstrated that enzyme biosensors based on carbon film resistor electrodes can be used for applications in complex matrixes. Nevertheless, more studies are needed to better evaluate the operational lifetime of these electrodes in different complex matrices and the possibilities of using them as electrode material for enzyme-based probes.

\section{Acknowledgements}

Financial support from Fundação para a Ciência e Tecnologia, Portugal (FCT), ICEMS, Portugal (Research Unit 103), European Projects QLK3-2000-01311 and HPRN-CT2002-00186 and the European Union Socrates programme are gratefully acknowledged. M.E.G. thanks FCT for a Ph.D. grant (SFRH/BD/14014/2003). Prof. H.-D. Liess is thanked for the gift of the electrical resistors.

\section{References}

[1] J.H. Tloung, C.A. Groom, K.B. Male, Biosens. Bioelectron. 6 (1991) 547

[2] W.A. Collier, D. Janssen, A.L. Hart, Biosens. Bioelectron. 11 (1996) 1041.

[3] A. Avramescu, T. Noguer, S. Andreescu, C. Calas-Blanchard, C. Bala, J.L. Marty, Talanta 59 (2003) 751.

[4] C.M.A. Brett, L. Angnes, H.-D. Liess, Electroanalysis 13 (2001) 765.

[5] O.M.S. Filipe, C.M.A. Brett, Electroanalysis 16 (2004) 994.

[6] M. Florescu, C.M.A. Brett, Talanta 65 (2005) 306.

[7] M. Florescu, C.M.A. Brett, Anal. Lett. 37 (2004) 871.

[8] A.A. Karyakin, O.V. Gitermacher, E.E. Karyakina, Anal. Chem. 67 (1995) 2419.

[9] F. Ricci, A. Amine, G. Palleschi, D. Moscone, Biosens. Bioelectron. 18 (2002) 165.

[10] E.A. Ulasova, L. Micheli, L. Vasii, D. Moscone, G. Palleschi, S.V. Vdovichev, A.V. Zoriv, S.A. Krutovertsev, E.E. Karyakina, A.A. Karyakin, Electroanalysis 15 (2003) 1 . 
[11] A.A. Karyakin, O.V. Gitelmacher, E.E. Karyakina, Anal. Lett. 27 (1994) 2861.

[12] A.A. Karyakin, E.E. Karyakina, L. Gorton, Electrochem. Comm. 1 (1999) 78.

[13] F.-D. Munteanu, A. Lindgren, J. Emneus, L. Gorton, T. Ruzgas, E. Csoregi, E.A. Ciucu, R.B. van Huystee, I.G. Gazaryan, L.M. Lagrimini, Anal. Chem. 70 (1998) 2596.

[14] Y. Kitagawa, K. Kitahatake, M. Suda, M. Muramatsu, T. Atoka, A. Mori, E. Tamiya, I. Karube, Anal. Chem. 63 (1991) 2391.

[15] S. Mirteus, J. Katrlik, A. Pazzariello, M. Stred'ansky, J. Svitel, J. Svork, Biosens. Bioelectron. 13 (1998) 911.

[16] A. Lupu, D. Compagnone, G. Palleschi, Anal. Chim. Acta 513 (2004) 67.

[17] M. Niculescu, R. Mieliauskiene, V. Laurinavicius, E. Csoregi, Food Chem. 82 (2003) 481.

[18] J. Razumiene, V. Gureviciene, A. Vilkanauskyte, L. Marcinkeviciene, I. Bachmatova, Sens. Actuators B 95 (2003) 378

[19] V. Laurinavicius, J. Razumiene, B. Kurtinaitiene, I. Lapenaite, I. Bachmatova, Bioelectrochemistry 55 (2002) 29.

[20] M. Esti, G. Volpe, L. Micheli, E. Delibato, D. Compagnone, D. Moscone, G. Palleschi, Anal. Chim. Acta 513 (2004) 357.
[21] A. Avramescu, T. Noguer, M. Avramescu, J.L. Marty, Anal. Chim. Acta 458 (2002) 203.

[22] B. Serra, A.J. Reviejo, C. Parrado, J.M. Pingarron, Biosens. Bioelectron. 14 (1999) 505.

[23] W. Khampha, V. Meevootisom, S. Wiyakrutta, Anal. Chim. Acta 520 (2004) 133

[24] A.A. Karyakin, Electroanalysis 13 (2001) 813.

[25] M. Esti, G. Volpe, D. Compagnone, G. Mariotti, D. Moscone, G. Palleschi, Am. J. Enol. Vitic. 54 (2003) 39.

[26] C. Qijin, D. Shaojun, Anal. Chim. Acta 310 (1995) 429.

[27] R. Garyonte, A. Malinauskas, Biosens. Bioelectron. 15 (2000) 445.

[28] W. Lu, G.G. Wallace, A.A. Karyakin, Electroanalysis 10 (1998) 472.

[29] A. Ivanov, G. Evtugyn, H. Budnikov, F. Ricci, D. Moscone, G. Palleschi, Anal. Bioanal. Chem. 377 (2003) 624.

[30] H. Tao, Z. XianEn, Z. ZhiPing, G. Feng, L. MuLong, Anal. Lett. 34 (1) (2001) 79 .

[31] G. Feng, Z. XianEn, Z. ZhiPing, Z. XiaoMei, Biosens. Bioelectron. 13 (1998) 333.

[32] E. Turkusic, J. Kalcher, E. Kahrovic, N.W. Beyene, H. Moderegger, E. Sofic, S. Begic, K. Kalcher, Talanta 65 (2005) 559.

[33] D.G. Altman, J.M. Bland, Lancet I (1986) 307. 